\title{
SUBSTITUTION OF SEMOLINA DURUM WITH COMMON WHEAT FLOUR IN EGG AND EGGLESS PASTA
}

\author{
Dorota Teterycz ${ }^{1}$, Aldona Sobota ${ }^{1 凶}$, Katarzyna Kozłowicz ${ }^{2}$, Piotr Zarzycki \\ ${ }^{1}$ Department of Plant Food Technology and Gastronomy, University of Life Sciences in Lublin \\ Skromna 8, 20-704 Lublin, Poland \\ ${ }^{2}$ Department of Biological Bases of Food and Feed Technologies, University of Life Sciences in Lublin \\ Głęboka 28, 20-612 Lublin, Poland
}

\begin{abstract}
Background. The aim of the study was to determine the possibility of full or partial replacement of durum semolina with cheaper common wheat flour to obtain high-quality pasta. It also examined whether the addition of eggs could minimize qualitative changes in these products.

Material and methods. In eggless, one-egg and two-egg pasta, semolina durum was substituted with common wheat flour to a degree of between 0-100\%. The study was carried out in semi-technical conditions with the use of a MAC 30S-Lab Pasta Extruder and an EAC 30-Lab Pasta Dryer. The physicochemical parameters and cooking quality of the pasta samples were tested.

Results. The results showed that the addition of the common wheat flour reduced the protein and dietary fibre content in the pasta, increased losses of dry matter during cooking, and decreased the yellowness index. However, it increased the weight increase index and shortened the cooking time. Adding eggs significantly improved the quality of the common wheat pasta.

Conclusion. On the basis of the tests carried out, it was found that the addition of common wheat flour to eggless and one-egg pasta should not exceed $50 \%$ and $60 \%$, respectively. It was shown that on adding two eggs, $100 \%$ of durum semolina could be replaced with common wheat flour without any significant deterioration in the quality of the product.
\end{abstract}

Keywords: pasta, common wheat flour, durum semolina, eggs

\section{INTRODUCTION}

Pasta is one of the most frequently consumed cereal products in the world. Because of constant changes in human lifestyle, pasta may become more popular due to its low price, ease of preparation, versatility of use, and good nutritional and sensory features (Rafiq et al., 2017). Producers in many countries often use cheaper common wheat flour instead of durum semolina, whose specific cultivation requirements and lower yield than common wheat significantly increase its price. However, pasta made from common wheat flour or from blends of common wheat flour with durum semolina is considered to be of lower quality than pasta from durum semolina, which is undoubtedly a product with the best quality parameters (Wiseman, 2001).

To improve the cooking quality, the colour, and especially the sensory characteristics of common wheat pasta, eggs are added. These may be whole eggs or only yolks, pasteurised, frozen or powdered eggs (Alamprese, 2017). Common wheat flour contains less protein, including gluten proteins, which results 
in lower product quality, lower firmness, and higher cooking losses. In addition, common wheat flour has finer granulation than durum semolina (Sobota et al., 2017). This parameter may induce higher cooking losses, enhance stickiness, and reduce pasta firmness, which results from a higher degree of damage to starch granules (Manthey and Twombly, 2013). Moreover, in comparison with semolina, common wheat flour contains lower amounts of carotenoids, which give a characteristic yellow colour (Leenhardt et al., 2006). Therefore, adding eggs to common wheat pasta seems necessary. Egg white contributes to the formation of a compact protein network in pasta, giving a firmer product. Egg albumin, the main egg-white protein, plays a major role in the formation of a tense network of proteins (Alamprese et al., 2005). Emerging new disulphide bonds (-S-S-) stabilize the gluten network responsible for the firmness and texture of products (Bonet et al., 2006; Sobota et al., 2015b). Additionally, lipids contained in the egg, especially monoacylglycerols and free fatty acids, interact with amylose while cooking the pasta and limit its solubility in water. This results in a smaller loss of dry matter during cooking and determines greater firmness and lower stickiness of the cooked pasta. Thanks to their high carotenoid content, egg yolks give pasta a yellower colour (Miranda et al., 2015; Švec et al., 2008). On the other hand, an increase in yolk content, and thus fat in pasta, weakens the gluten structure (Alamprese, 2017).

The addition of eggs determines not only the cooking quality of pasta but also its nutritional value. Eggs contain trace amounts of carbohydrates, about $12 \%$ protein, and about $12 \%$ fat, most of which is in the form of monounsaturated fatty acids (Miranda et al., 2015; Ruxton et al., 2010). Moreover, eggs are a source of choline, folic acid, iron, calcium, fat-soluble vitamins (A, D, E, K), and B vitamins (B2, B6, B12) (Abdou et al., 2013). Besides its emulsifying properties used in food production, lecithin in egg yolks also supports proper functioning of cell membranes (Miranda et al., 2015). The carotenoids responsible for the orange-yellow colour of yolk have strong antioxidant properties (Rakonjac et al., 2014). Egg protein contains all essential amino acids in balanced proportions; hence, it can supplement a pasta protein with a limiting amino acid in wheat, i.e. lysine (Watkins, 1995).
Although it has been confirmed that durum semolina is the best raw material for the production of pasta and the addition of common wheat flour lowers the quality of the product (Sobota et al., 2017), there are no results of studies determining the optimal composition of mixing the two raw materials in order to reduce production costs and obtain pasta with satisfactory quality parameters. These studies were undertaken to determine to what extent durum semolina can be substituted with common wheat flour without causing any significant deterioration in the quality of pasta. It was also investigated whether the negative effect of the addition of common wheat flour on the cooking quality of pasta could be minimized by adding eggs. Therefore, the study allowed the authors to determine the optimal composition of a mixture of durum semolina with common wheat flour with the possible addition of eggs to obtain good-quality pasta.

\section{MATERIALS AND METHODS}

\section{Raw materials}

The raw materials used in the study included durum semolina (TDD - Durum Wheaten Flour for Pastas 25/1, ash max. $0.85 \%$ ) produced by Julia Malom (Kunszallas, Hungary), common wheat flour (type 450) produced by PZZ Kraków (Cracow, Poland), and liquid pasteurized whole egg produced by Oval (Malbork, Poland).

\section{Fractional composition of wheat materials}

The particle size of the semolina durum and common wheat flour was determined using the method described by Sobota et al. (2015a).

\section{Production of pasta}

The pasta samples were produced in semi-technical laboratory conditions, using a MAC 30S-Lab Pasta Extruder (ItalPast, Fidenza, Italy). The raw materials, i.e. common wheat flour, durum semolina, liquid pasteurized whole egg and water, were combined in appropriate proportions (Table 1) to make a dough with a moisture content of $31-32 \%$. The model assumes that $50 \mathrm{~g}$ of pasteurized liquid egg mass is equivalent to one egg. The raw materials were mixed together for 15 minutes in a premixer. The resulting blends were extruded at a low temperature $\left(28^{\circ} \mathrm{C}\right)$ in an extrusion 
Teterycz, D., Sobota, A., Kozłowicz, K., Zarzycki, P. (2019). Substitution of semolina durum with common wheat flour in egg and eggless pasta. Acta Sci. Pol. Technol. Aliment., 18(4), 439-451. http://dx.doi.org/10.17306/J.AFS.2019.0722

Table 1. Model of experiment

\begin{tabular}{|c|c|c|c|}
\hline \multirow{2}{*}{ Sample } & $\begin{array}{l}\text { Semolina } \\
\text { durum }\end{array}$ & $\begin{array}{c}\text { Common wheat } \\
\text { flour }\end{array}$ & \multirow{2}{*}{$\begin{array}{c}\text { Eggs } \\
\text { piece } / \mathrm{kg} \\
\text { wheat raw } \\
\text { material }\end{array}$} \\
\hline & \multicolumn{2}{|r|}{$\%$} & \\
\hline WF0/0E & 100 & 0 & \\
\hline WF10/0E & 90 & 10 & \\
\hline WF20/0E & 80 & 20 & \\
\hline WF30/0E & 70 & 30 & \\
\hline WF40/0E & 60 & 40 & \\
\hline WF50/0E & 50 & 50 & 0 \\
\hline WF60/0E & 40 & 60 & \\
\hline WF70/0E & 30 & 70 & \\
\hline WF80/0E & 20 & 80 & \\
\hline WF90/0E & 10 & 90 & \\
\hline WF100/0E & 0 & 100 & \\
\hline WF0/1E & 100 & 0 & \\
\hline WF10/1E & 90 & 10 & \\
\hline WF20/1E & 80 & 20 & \\
\hline WF30/1E & 70 & 30 & \\
\hline WF40/1E & 60 & 40 & \\
\hline WF50/1E & 50 & 50 & 1 \\
\hline WF60/1E & 40 & 60 & \\
\hline WF70/1E & 30 & 70 & \\
\hline WF80/1E & 20 & 80 & \\
\hline WF90/1E & 10 & 90 & \\
\hline WF100/1E & 0 & 100 & \\
\hline WF0/2E & 100 & 0 & \\
\hline WF10/2E & 90 & 10 & \\
\hline WF20/2E & 80 & 20 & \\
\hline WF30/2E & 70 & 30 & \\
\hline WF40/2E & 60 & 40 & \\
\hline WF50/2E & 50 & 50 & 2 \\
\hline WF60/2E & 40 & 60 & \\
\hline WF70/2E & 30 & 70 & \\
\hline WF80/2E & 20 & 80 & \\
\hline WF90/2E & 10 & 90 & \\
\hline WF100/2E & 0 & 100 & \\
\hline
\end{tabular}

WF - common wheat flour, E - egg. barrel with a water-cooling jacket and at a vacuum level of 110 bar. Teflon dies were used during extrusion. Pasta samples (Fusilli) were dried in a EAC 30-Lab Pasta Dryer (ItalPast, Fidenza, Italy) using a profile of low temperatures $\left(30-45^{\circ} \mathrm{C}\right)$ and $74-50 \%$ relative humidity of the drying air (Fig. 1).

\section{Chemical composition of raw materials and pasta samples}

The chemical composition was analysed to determine the protein, fat, dietary fibre, moisture, and ash contents. The content of total dietary fibre (TDF) in the pasta samples and raw materials was determined using enzymatic methods from the American Association of Cereal Chemists (AACC) and the Association of Analytical Communities (AOAC; AACC 32-05, AACC 32-21, AOAC 991.43, AOAC 985-29). The water content was determined by means of the air-oven method (AACC 44-15A) and the ash content was assessed using the basic method (AACC 08-01). The protein content was determined using a Kjeltec ${ }^{\mathrm{TM}} 8400$ machine with the ASN (Application Sub Notes) 3100 application. Distillation was carried out in a Kjeltec Auto automatic device (Tecator). Fat was determined by continuous extraction using ether in a Soxtec ${ }^{\mathrm{TM}} 8000$ machine with the AN 310 application. The content of available carbohydrates was calculated from the difference. The wet gluten content in the wheat raw materials was assessed using the hand-washing method (AACC 38-10; AACC, 2000; AOAC, 1992). The energy value for the pasta samples was calculated using a modified Atwater factor (protein - 4 kcal, carbohydrate $-4 \mathrm{kcal}$, fat $-9 \mathrm{kcal}, \mathrm{TDF}-2 \mathrm{kcal})$. The chemical composition of the raw materials and the pasta was repeated in three trials.

\section{Cooking quality of pasta samples}

The minimum cooking time was determined after removing the pasta samples from boiling distilled water every 15 seconds and squeezing them between two transparent plates. The minimum cooking time is the time after which the white core in the squeezed pasta disappears. The weight increase index (WII) of the pasta was determined as a ratio between the weight of cooked and uncooked pasta. Cooking loss was assessed by determining the dry matter content in water after cooking for the minimum cooking time (AACC 
Teterycz, D., Sobota, A., Kozłowicz, K., Zarzycki, P. (2019). Substitution of semolina durum with common wheat flour in egg and eggless pasta. Acta Sci. Pol. Technol. Aliment., 18(4), 439-451. http://dx.doi.org/10.17306/J.AFS.2019.0722

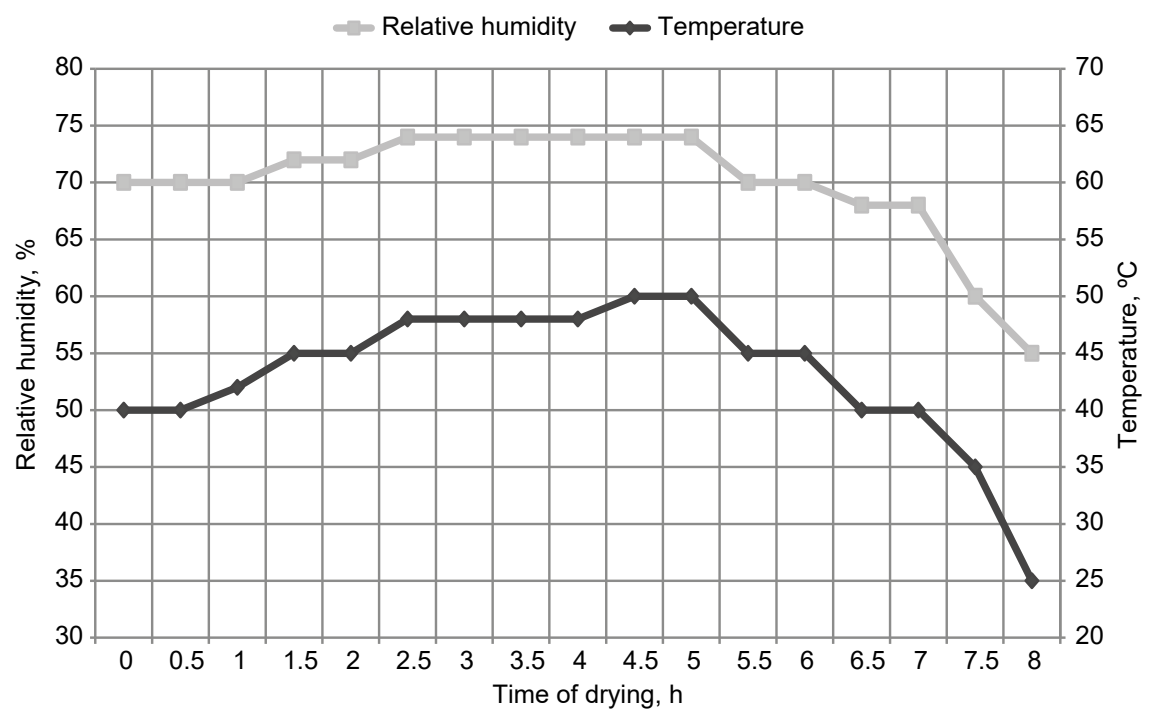

Fig. 1. Changes in the pasta drying parameters

Method 44-15A). Overcooking loss was evaluated by assaying the content of total solids in the water after cooking for a time prolonged by $50 \%$ in relation to the minimum cooking time. This method of determining the cooking quality parameters of the pasta was repeated in three tests.

\section{The colour of cooked and uncooked pasta}

The colour parameters of raw and cooked pasta were determined with a reflective method using a spherical spectrophotometer 8200 (X-Rate, Inc. USA). The procedure for colour measurement was described by Teterycz et al. (2019). Changes in the colour of the pasta samples (raw and cooked) were established. The parameters of the pasta were determined on the basis of the results of ten repetitions (Table 5). The yellowness index value for raw and cooked pasta was calculated from the Francis and Clydesdale formula (1975):

$$
\mathrm{YI}=142.86 b^{*} / L^{*}
$$

\section{Evaluation criteria for pasta samples}

In order to assess the quality of pasta precisely, five quality criteria were adopted, in which the following parameters were determined: protein and fibre content, yellowness index (YI) for raw and cooked pasta, and loss of dry matter during cooking. According to
Italian standards, semolina pasta should not contain less than $11.5 \%$ protein (Regolamento..., 1994). This value was adopted as one of the evaluation criteria for pasta. It was also found that an important parameter for evaluating pasta is its fibre content. It was assumed that this value should not be lower than $10 \%$ of the daily fibre requirement for $100 \mathrm{~g}$ of raw pasta, i.e. $3.80 \%$ (USDA, 2015). It is also assumed that in the case of good-quality pasta, cooking losses should not exceed 8\% (Dick and Youngs, 1988), which is also accepted as a quality criterion. In addition, knowing that consumers pay particular attention to the appearance of pasta, the YI criterion was set on the basis of the literature (Jyotsna et al., 2004) at a level not lower than 30 and 20 for raw and cooked pasta, respectively.

\section{Statistical analysis}

The mean values and standard deviations were calculated. The results were statistically analyzed using twoway analysis of variance with replication (ANOVA, STATISTICA 13, StatSoft, Inc., Tulsa, USA) with two factors: addition of common wheat flour and eggs. In order to determine significance difference between mean value, the Tukey HSD test $(p<0.05)$ was used. Moreover, the values of the correlation coefficient between the chemical composition of pasta and cooking quality features were determined (Pearson, $p<0.05$ ). 


\section{RESULTS AND DISCUSSION}

\section{Raw material analysis}

The sieve analysis showed significant differences in the substitution value for the semolina and common wheat flour studied (Table 2). As suggested by Dalbon et al. (1996), the equivalent diameter of semolina for pasta production should range from $250-350 \mu \mathrm{m}$. The value of this parameter for the raw material used in the study was within the given range. Coarse granulation of semolina may result in greater firmness of pasta made only of semolina or with a high semolina content (Manthey and Twombly, 2013). It can also contribute to lower cooking losses, which is explained by a lower degree of damage to starch granules during milling. As shown by the authors, gelatinized starch largely contributes to an increase in cooking losses (Marti et al., 2014). The content of gluten in the wheat raw materials used in the present study varied (Table 2). The high gluten content in semolina $(30.79 \%)$ determines the high cooking quality of the pasta and reduction of cooking losses in comparison to common wheat flour pasta. High gluten content in the raw material is also responsible for formation of a strong protein matrix in the pasta, which prevents the starch from rupturing during cooking, additionally improving the texture parameters of the product (Diantom et al., 2016; Sobota and Zarzycki, 2013). Therefore, such pasta is also more resistant to overcooking. Nevertheless, the high gluten content results in a lower weight increase index for the pasta (Fuad and Prabhasankar, 2010). The TDF content in the flour raw materials was higher in semolina $(5.15 \%$ d.m.) than in common wheat flour $(4.19 \%$ d.m.), while the eggs contained trace amounts of TDF $(0.10 \%$ d.m. $)$. The pasteurized egg mass was characterized by a high protein content (52.93\% d.m.). Egg protein contains all the essential amino acids in the right proportions; hence, they can supplement the amino acid composition of the pasta and improve its nutritional value. The eggs were also rich in fat $(40.90 \%$ d.m.) and minerals determined as ash $(4.46 \%$ d.m.).

\section{Chemical composition of pasta}

The nutrient content and energy value of the pasta are given in Table 3. The content of individual nutrients varies statistically depending on the raw material composition of the sample. Protein, as a determinant of the cooking quality of pasta, is one of the most important components of pasta. The protein content in the samples was within the range of $11.09-14.48 \%$ d.m. Its content changed significantly with the increased addition of common wheat flour, which contains less protein than semolina durum. Nevertheless, the increase in the protein content was influenced by the addition of eggs. The addition of two eggs increased the content of protein in the samples by about $1.44-1.69 \%$ d.m. Filipovic et al. (2014) noted that three eggs increased the protein content in pasta by $1.34 \% \mathrm{~d} . \mathrm{m}$. Taking into account the target set in the study, only the WF80/0EWF100/0E samples did not meet the protein content criterion of at least $11.5 \%$ d.m.

The fat content, like the protein content, decreased with the proportion of common wheat flour. According

Table 2. Physicochemical features of raw materials

\begin{tabular}{lcccccccc}
\hline Raw material & $\begin{array}{c}\text { Wet gluten } \\
\%\end{array}$ & $\begin{array}{c}\text { Equivalent } \\
\text { diameter } \\
\mu \mathrm{m}\end{array}$ & $\begin{array}{c}\text { Moisture } \\
\%\end{array}$ & Protein & Fat & TDF & Ash & $\begin{array}{c}\text { Carbo- } \\
\text { hydrates }\end{array}$ \\
\cline { 8 - 10 } & & & & & $\%$ d.m. & & \\
\hline $\begin{array}{l}\text { Semolina } \\
\text { durum }\end{array}$ & $30.79^{\mathrm{a}} \pm 0.17$ & $269.74^{\mathrm{a}} \pm 0.46$ & $13.59^{\mathrm{b}} \pm 0.02$ & $12.92^{\mathrm{c}} \pm 0.01$ & $0.42^{\mathrm{b}} \pm 0.01$ & $5.15^{\mathrm{a}} \pm 0.15$ & $0.81^{\mathrm{b}} \pm 0.02$ & $80.77^{\mathrm{c}}$ \\
$\begin{array}{l}\text { Common } \\
\text { wheat flour }\end{array}$ & $27.78^{\mathrm{b}} \pm 0.15$ & $144.69^{\mathrm{b}} \pm 1.08$ & $10.75^{\mathrm{b}} \pm 0.02$ & $10.03^{\mathrm{b}} \pm 0.02$ & $0.19^{\mathrm{c}} \pm 0.00$ & $4.19^{\mathrm{b}} \pm 0.12$ & $0.44^{\mathrm{c}} \pm 0.01$ & $85.15^{\mathrm{a}}$ \\
$\begin{array}{l}\text { Pasteurized } \\
\text { egg mass }\end{array}$ & - & - & $76.46^{\mathrm{a}} \pm 0.02$ & $52.93^{\mathrm{a}} \pm 0.01$ & $40.90^{\mathrm{a}} \pm 0.02$ & $0.10^{\mathrm{c}} \pm 0.01$ & $4.46^{\mathrm{a}} \pm 0.04$ & $1.61^{\mathrm{b}}$ \\
\hline
\end{tabular}

Means $(n=3)$ with different letters in the same column are significantly different $(P<0.05)$. 
Teterycz, D., Sobota, A., Kozłowicz, K., Zarzycki, P. (2019). Substitution of semolina durum with common wheat flour in egg and eggless pasta. Acta Sci. Pol. Technol. Aliment., 18(4), 439-451. http://dx.doi.org/10.17306/J.AFS.2019.0722

Table 3. Chemical composition of pasta samples

\begin{tabular}{|c|c|c|c|c|c|c|c|}
\hline \multirow[t]{2}{*}{ Sample } & \multirow{2}{*}{$\begin{array}{c}\text { Moisture } \\
\%\end{array}$} & Protein & Fat & TDF & Ash & $\begin{array}{c}\text { Carbohy- } \\
\text { drates }\end{array}$ & \multirow{2}{*}{$\begin{array}{l}\text { Energy value } \\
\mathrm{kcal} / 100 \mathrm{~g} \mathrm{~d} . \mathrm{m} .\end{array}$} \\
\hline & & \multicolumn{5}{|c|}{$\%$ d.m. } & \\
\hline WF0/0E & $10.08^{\mathrm{bc}} \pm 0.01$ & $12.88^{\mathrm{n}} \pm 0.01$ & $0.27^{\mathrm{gh}} \pm 0.01$ & $5.05^{\text {bcd }} \pm 0.10$ & $0.73^{\text {ghi }} \pm 0.01$ & 82.38 & 388.23 \\
\hline WF10/0E & $10.08^{\mathrm{bc}} \pm 0.06$ & $12.72^{\circ} \pm 0.01$ & $0.24^{\mathrm{h}} \pm 0.01$ & $4.95^{\text {cdef }} \pm 0.04$ & $0.69^{\text {hijk }} \pm 0.03$ & 82.70 & 388.38 \\
\hline WF20/0E & $10.43^{\mathrm{ab}} \pm 0.26$ & $12.54^{\mathrm{q}} \pm 0.02$ & $0.23^{\mathrm{h}} \pm 0.02$ & $4.74^{\text {defgh }} \pm 0.04$ & $0.67^{\mathrm{jklm}} \pm 0.00$ & 83.13 & 388.77 \\
\hline WF30/0E & $10.45^{\mathrm{ab}} \pm 0.02$ & $12.40^{\mathrm{r}} \pm 0.01$ & $0.22^{\mathrm{h}} \pm 0.00$ & $4.53^{\text {fghij }} \pm 0.08$ & $0.62^{\mathrm{mno}} \pm 0.01$ & 83.54 & 389.49 \\
\hline WF40/0E & $10.57^{\mathrm{ab}} \pm 0.09$ & $12.17^{\varsigma} \pm 0.01$ & $0.20^{\mathrm{h}} \pm 0.00$ & $4.44^{\text {ghijk }} \pm 0.03$ & $0.58^{\text {opq }} \pm 0.02$ & 83.92 & 389.72 \\
\hline WF50/0E & $10.85^{\mathrm{ab}} \pm 0.25$ & $12.00^{t} \pm 0.01$ & $0.21^{\mathrm{h}} \pm 0.02$ & $4.26^{\mathrm{ijklm}} \pm 0.01$ & $0.57^{\mathrm{pq}} \pm 0.02$ & 84.29 & 390.22 \\
\hline WF60/0E & $10.45^{\mathrm{ab}} \pm 0.17$ & $11.75^{\mathrm{u}} \pm 0.04$ & $0.23^{\mathrm{h}} \pm 0.00$ & $4.17^{\mathrm{jklm}} \pm 0.01$ & $0.51^{\mathrm{rs}} \pm 0.01$ & 84.60 & 390.49 \\
\hline WF70/0E & $10.69^{\mathrm{ab}} \pm 0.04$ & $11.62^{\mathrm{v}} \pm 0.02$ & $0.21^{\mathrm{h}} \pm 0.02$ & $4.11^{\mathrm{jklm}} \pm 0.09$ & $0.48^{\text {st }} \pm 0.03$ & 84.85 & 390.72 \\
\hline WF80/0E & $11.03^{\mathrm{a}} \pm 0.22$ & $11.38^{\mathrm{w}} \pm 0.02$ & $0.18^{\mathrm{h}} \pm 0.00$ & $3.98^{\mathrm{klm}} \pm 0.03$ & $0.44^{\mathrm{tu}} \pm 0.00$ & 85.30 & 391.16 \\
\hline WF90/0E & $11.07^{\mathrm{a}} \pm 0.00$ & $11.12^{x} \pm 0.01$ & $0.19^{\mathrm{h}} \pm 0.01$ & $3.92^{\operatorname{lm}} \pm 0.01$ & $0.39^{\mathrm{uv}} \pm 0.00$ & 85.63 & 391.39 \\
\hline WF100/0E & $10.82^{\mathrm{ab}} \pm 0.06$ & $11.09^{\mathrm{y}} \pm 0.01$ & $0.17^{\mathrm{h}} \pm 0.02$ & $3.87^{\mathrm{m}} \pm 0.06$ & $0.36^{\mathrm{v}} \pm 0.00$ & 85.88 & 391.60 \\
\hline WF0/1E & $10.16^{\mathrm{bc}} \pm 0.07$ & $14.27^{\mathrm{c}} \pm 0.01$ & $0.58^{\mathrm{f}} \pm 0.02$ & $5.08^{\mathrm{bcd}} \pm 0.26$ & $0.95^{\mathrm{a}} \pm 0.01$ & 80.43 & 388.66 \\
\hline WF10/1E & $8.65^{\mathrm{de}} \pm 0.17$ & $13.91^{\mathrm{d}} \pm 0.01$ & $0.53^{\mathrm{f}} \pm 0.01$ & $4.96^{\text {cdef }} \pm 0.06$ & $0.90^{\mathrm{b}} \pm 0.01$ & 80.81 & 388.95 \\
\hline WF20/1E & $8.44^{\text {de }} \pm 0.04$ & $13.83^{\mathrm{e}} \pm 0.01$ & $0.53^{\mathrm{f}} \pm 0.00$ & $4.85^{\text {cdefg }} \pm 0.09$ & $0.86^{\mathrm{cd}} \pm 0.03$ & 81.21 & 389.34 \\
\hline WF30/1E & $10.24^{\mathrm{bc}} \pm 0.13$ & $13.75^{\mathrm{f}} \pm 0.01$ & $0.52^{\mathrm{f}} \pm 0.02$ & $4.72^{\text {defghi }} \pm 0.20$ & $0.81^{\mathrm{de}} \pm 0.02$ & 81.59 & 389.69 \\
\hline WF40/1E & $8.58^{\text {de }} \pm 0.24$ & $13.48^{\mathrm{g}} \pm 0.01$ & $0.50^{\mathrm{f}} \pm 0.02$ & $4.53^{\text {efghij }} \pm 0.06$ & $0.75^{\mathrm{fg}} \pm 0.02$ & 81.91 & 390.16 \\
\hline WF50/1E & $8.75^{\mathrm{de}} \pm 0.59$ & $13.45^{\mathrm{gh}} \pm 0.01$ & $0.51^{\mathrm{f}} \pm 0.02$ & $4.52^{\text {fghij }} \pm 0.08$ & $0.71^{\text {hijk }} \pm 0.01$ & 82.24 & 390.43 \\
\hline WF60/1E & $10.80^{\mathrm{ab}} \pm 0.10$ & $13.27^{1} \pm 0.02$ & $0.52^{\mathrm{f}} \pm 0.00$ & $4.41^{\mathrm{ghijk}} \pm 0.10$ & $0.67^{\mathrm{jk} 1} \pm 0.01$ & 82.42 & 390.80 \\
\hline WF70/1E & $8.76^{\mathrm{de}} \pm 0.05$ & $12.94^{\circ} \pm 0.02$ & $0.50^{\text {fg }} 0.02$ & $4.32^{\mathrm{hijklm}} \pm 0.23$ & $0.63^{\operatorname{lmn}} \pm 0.01$ & 82.73 & 391.12 \\
\hline WF80/1E & $10.31^{\mathrm{b}} \pm 0.09$ & $12.75^{\mathrm{p}} \pm 0.01$ & $0.54^{\mathrm{g}} \pm 0.01$ & $4.23^{\mathrm{jklm}} \pm 0.15$ & $0.61^{\text {nop }} \pm 0.03$ & 83.25 & 391.57 \\
\hline WF90/1E & $9.63^{c} \pm 0.16$ & $12.54^{q} \pm 0.01$ & $0.53^{\mathrm{g}} \pm 0.01$ & $4.16^{\mathrm{jklm}} \pm 0.07$ & $0.59^{\text {nop }} \pm 0.01$ & 83.43 & 391.70 \\
\hline WF100/1E & $8.87^{\mathrm{d}} \pm 0.24$ & $12.24^{r} \pm 0.01$ & $0.50^{\mathrm{fg}} \pm 0.02$ & $4.06^{\mathrm{jlm}} \pm 0.12$ & $0.55^{\mathrm{qr}} \pm 0.03$ & 83.71 & 391.78 \\
\hline $\mathrm{WF} 0 / 2 \mathrm{E}$ & $8.32^{\mathrm{de}} \pm 0.03$ & $14.48^{\mathrm{a}} \pm 0.02$ & $1.54^{\mathrm{a}} \pm 0.01$ & $5.62^{\mathrm{a}} \pm 0.16$ & $0.97^{\mathrm{a}} \pm 0.01$ & 78.90 & 392.09 \\
\hline WF10/2E & $8.20^{\text {ef }} \pm 0.10$ & $14.40^{\mathrm{b}} \pm 0.00$ & $1.33^{\mathrm{abcd}} \pm 0.27$ & $5.45^{\mathrm{ab}} \pm 0.08$ & $0.89^{\mathrm{bc}} \pm 0.00$ & 79.33 & 391.64 \\
\hline WF20/2E & $8.46^{\mathrm{de}} \pm 0.08$ & $14.01^{\mathrm{d}} \pm 0.02$ & $1.43^{\mathrm{ab}} \pm 0.15$ & $5.28^{\mathrm{abc}} \pm 0.11$ & $0.88^{\mathrm{bc}} \pm 0.01$ & 79.71 & 392.51 \\
\hline WF30/2E & $8.70^{\mathrm{de}} \pm 0.10$ & $14.01^{\mathrm{d}} \pm 0.01$ & $1.40^{\mathrm{abc}} \pm 0.01$ & $5.12^{\mathrm{bcd}} \pm 0.04$ & $0.83^{\mathrm{de}} \pm 0.00$ & 79.98 & 392.87 \\
\hline WF40/2E & $8.48^{\mathrm{de}} \pm 0.10$ & $13.73^{\mathrm{e}} \pm 0.00$ & $1.35^{\mathrm{abcd}} \pm 0.01$ & $5.00^{\text {bcde }} \pm 0.10$ & $0.79^{\mathrm{ef}} \pm 0.01$ & 80.41 & 393.02 \\
\hline WF50/2E & $8.48^{\mathrm{de}} \pm 0.09$ & $13.44^{\mathrm{g}} \pm 0.01$ & $1.11^{\mathrm{de}} \pm 0.08$ & $4.94^{\text {cdef }} \pm 0.06$ & $0.73^{\text {ghi }} \pm 0.00$ & 81.02 & 392.28 \\
\hline WF60/2E & $8.63^{\mathrm{de}} \pm 0.15$ & $13.38^{\mathrm{j}} \pm 0.01$ & $1.13^{\text {de }} \pm 0.09$ & $4.88^{\text {cdefg }} \pm 0.10$ & $0.72^{\text {ghij }} \pm 0.00$ & 81.14 & 392.55 \\
\hline WF70/2E & $8.83^{\mathrm{de}} \pm 0.52$ & $13.09^{\mathrm{k}} \pm 0.01$ & $1.19^{\mathrm{bcd}} \pm 0.02$ & $4.79^{\text {defgh }} \pm 0.21$ & $0.67^{\mathrm{klm}} \pm 0.01$ & 81.42 & 393.03 \\
\hline WF80/2E & $8.59^{\mathrm{de}} \pm 0.21$ & $12.99^{1} \pm 0.07$ & $1.16^{\mathrm{cd}} \pm 0.02$ & $4.52^{\text {fghij }} \pm 0.16$ & $0.63^{\mathrm{mn}} \pm 0.01$ & 81.91 & 394.04 \\
\hline WF90/2E & $8.84^{\mathrm{de}} \pm 0.04$ & $12.82^{\mathrm{m}} \pm 0.03$ & $1.14^{\mathrm{de}} \pm 0.01$ & $4.35^{\mathrm{hijkl}} \pm 0.09$ & $0.61^{\text {nop }} \pm 0.01$ & 82.32 & 394.17 \\
\hline WF100/2E & $8.92^{\mathrm{d}} \pm 0.06$ & $12.53^{\circ} \pm 0.03$ & $0.91^{\mathrm{e}} \pm 0.02$ & $4.19^{\mathrm{jklm}} \pm 0.14$ & $0.60^{\text {nop }} \pm 0.00$ & 82.87 & 393.33 \\
\hline
\end{tabular}

WF - common wheat flour, E - egg.

Means $(n=3)$ with different letters in the same column are significantly different $(P<0.05)$. 
to Polish standards (PN-A-74131:1999), eggless common wheat pasta should contain approx. $0.4 \%$ free fat, while adding each egg should increase this value by approximately $0.5 \%$ (Sobota et al., 2015b). As expected, the samples of pasta with added eggs showed a significant increase in the free fat content; however, these values are lower than those assumed by the Polish standards. The differences may result from different methods for determining free fat and the use of different solvents for fat extraction.

Dietary fibre is a very important functional component of the human diet, especially nowadays, when there is a continuous increase in the incidence of civilization diseases such as diabetes, obesity or cardiovascular diseases (Mehta et al., 2015). Cereal products are a valuable source of dietary fibre, consumption of which can improve human health (Mann and Cummings, 2009). The addition of common wheat flour at a level of above $30 \%$ significantly decreased the fibre content in the eggless samples. In the case of the one-egg and two-egg samples, a significant decrease in the fibre content was observed for samples with $40 \%$ and $30 \%$ addition of common wheat flour, respectively. The addition of one egg to the common wheat flour samples did not cause any significant differences in the fibre content compared to the control (WF100/0E), and when two eggs were added, this difference was statistically significant. However, in the semolina samples, especially those with the addition of two eggs, these differences increased. The higher fibre content of the semolina samples may result from the formation of complexes between starch and lipids during extrusion and drying. The ability to bind lipids is mainly related to the amylose starch fraction due to its linear structure. As demonstrated in the literature, durum wheat contains more amylose than common wheat (Lafiandra et al., 2012). With the addition of eggs, the fat content increased, which suggests higher content of amylose and lipid complexes in those samples. Amylose-lipid complexes are classified as RS5 (RS - resistant starch), which is attributed to the properties of dietary fibre such as a reduction in the $\mathrm{pH}$ in the colon and postprandial glycaemia or prevention of colon cancer (Panyoo and Emmambux, 2017). The analysis of the fibre content results in terms of meeting the minimum $3.8 \%$ criterion showed that all the samples met the criterion.
Significant differences in the ash content were noted in the samples tested. The increase was related to the share of semolina durum in pasta as well as the egg content.

\section{Cooking quality of pasta}

Cooking time is one of the most important quality parameters of pasta for consumers. They expect the product to take as little time as possible to prepare. The minimum cooking time depends mainly on the protein content in the pasta. High levels of gluten proteins, which form a strong matrix, limit the access of water to the starch, thus prolonging the time of starch gelatinization. It may also be influenced by the thicker granulation of semolina (Grant et al., 1993; Sobota et al., 2015b). Each egg added also prolonged the cooking time by improving the continuity of the proteinstarch matrix. The addition of one egg to a sample made from common wheat flour prolonged the cooking time by 1 minute, while the addition of two eggsprolonged it by 2 minutes (Table 4). The greatest cooking time differences between the common wheat flour pasta and the semolina pasta were recorded for eggless pasta (1.25-minute increase), while the difference decreased with the addition of one or two eggs (1- and 0.75 -minute increase, respectively). It can therefore be concluded that adding eggs has a greater effect on the cooking time of common wheat flour pasta than semolina pasta, probably through more intensive strengthening of the protein matrix.

The weight increase index (WII) of pasta indicates its ability to absorb water during cooking. Higher absorption is usually related to a high starch content in the product, while lower WII values are recorded for products with a high protein content (Sozer nad Kaya, 2008). This is confirmed by the results of the correlation analysis between the chemical composition and the cooking quality features of the pasta samples tested (Table 6). The WII in the samples increased with the addition of common wheat flour to the sample. It is determined by the lower protein content in these samples, finer granulation of raw material, and higher starch content. As shown by the literature, the addition of eggs increases the WII of pasta during cooking (Savita et al., 2013). In this research, the highest WII was recorded for the two-egg samples. As reported by Lambrecht et al. (2017), the level of water absorption 
Teterycz, D., Sobota, A., Kozłowicz, K., Zarzycki, P. (2019). Substitution of semolina durum with common wheat flour in egg and eggless pasta. Acta Sci. Pol. Technol. Aliment., 18(4), 439-451. http://dx.doi.org/10.17306/J.AFS.2019.0722

Table 4. Cooking quality of pasta samples

\begin{tabular}{|c|c|c|c|c|}
\hline Sample & $\begin{array}{l}\text { Minimal cooking time } \\
\text { min }\end{array}$ & $\begin{array}{l}\text { Weight increase } \\
\text { index }\end{array}$ & $\begin{array}{l}\text { Cooking loss } \\
\text { \% d.m. }\end{array}$ & $\begin{array}{l}\text { Overcooking } \\
\text { loss }\end{array}$ \\
\hline WF0/0E & $8.25^{\mathrm{f}} \pm 0.08$ & $2.15^{\mathrm{n}} \pm 0.06$ & $5.33^{\mathrm{jk}} \pm 0.05$ & $5.76^{\mathrm{klmop}} \pm 0.15$ \\
\hline WF10/0E & $8.00^{\mathrm{g}} \pm 0.06$ & $2.17^{\mathrm{mn}} \pm 0.01$ & $5.43^{\mathrm{ij}} \pm 0.03$ & $5.90^{\mathrm{klm}} \pm 0.19$ \\
\hline WF20/0E & $7.75^{\mathrm{h}} \pm 0.27$ & $2.21^{\mathrm{klmn}} \pm 0.01$ & $5.45^{\mathrm{hi}} \pm 0.02$ & $6.36^{\mathrm{ijk}} \pm 0.21$ \\
\hline WF30/0E & $7.50^{\mathrm{i}} \pm 0.01$ & $2.22^{\mathrm{jklmn}} \pm 0.01$ & $5.70^{\mathrm{fgh}} \pm 0.09$ & $6.51^{\mathrm{hij}} \pm 0.28$ \\
\hline $\mathrm{WF} 40 / 0 \mathrm{E}$ & $7.50^{\mathrm{i}} \pm 0.05$ & $2.24^{\mathrm{hijklm}} \pm 0.01$ & $5.88^{\text {cde }} \pm 0.04$ & $6.81^{\text {ghi }} \pm 0.16$ \\
\hline WF50/0E & $7.50^{\mathrm{i}} \pm 0.12$ & $2.25^{\text {ghijkl }} \pm 0.01$ & $5.86^{\mathrm{cdef}} \pm 0.04$ & $7.57^{\mathrm{def}} \pm 0.11$ \\
\hline WF60/0E & $7.50^{\mathrm{i}} \pm 0.13$ & $2.28^{\mathrm{fghij}} \pm 0.01$ & $5.92^{\text {bcde }} \pm 0.04$ & $7.82^{\text {cde }} \pm 0.13$ \\
\hline WF70/0E & $7.50^{\mathrm{i}} \pm 0.05$ & $2.30^{\text {efgh }} \pm 0.01$ & $6.03^{\mathrm{bc}} \pm 0.05$ & $8.25^{\mathrm{cd}} \pm 0.11$ \\
\hline WF80/0E & $7.50^{\mathrm{i}} \pm 0.03$ & $2.30^{\mathrm{efgh}} \pm 0.01$ & $6.08^{\mathrm{ab}} \pm 0.10$ & $8.29^{\text {cd }} \pm 0.20$ \\
\hline WF90/0E & $7.25^{\mathrm{j}} \pm 0.29$ & $2.31^{\text {defgh }} \pm 0.01$ & $6.21^{\mathrm{a}} \pm 0.15$ & $8.51^{\mathrm{bc}} \pm 0.04$ \\
\hline WF100/0E & $7.00^{\mathrm{k}} \pm 0.14$ & $2.32^{\text {cdefg }} \pm 0.01$ & $6.25^{\mathrm{a}} \pm 0.12$ & $8.63^{a} \pm 0.11$ \\
\hline WF0/1E & $9.00^{\mathrm{d}} \pm 0.29$ & $2.20^{\mathrm{lmn}} \pm 0.01$ & $5.07^{\mathrm{on}} \pm 0.01$ & $5.30^{\text {nop }} \pm 0.01$ \\
\hline WF10/1E & $9.00^{\mathrm{d}} \pm 0.29$ & $2.23^{\mathrm{ijklm}} \pm 0.01$ & $5.12^{\operatorname{lmno}} \pm 0.01$ & $5.47^{\mathrm{lmnop}} \pm 0.09$ \\
\hline WF20/1E & $9.00^{\mathrm{d}} \pm 0.25$ & $2.22^{\mathrm{ijklm}} \pm 0.01$ & $5.26^{\mathrm{kl}} \pm 0.03$ & $5.76^{\mathrm{klm}} \pm 0.01$ \\
\hline WF30/1E & $9.00^{\mathrm{d}} \pm 0.25$ & $2.24^{\mathrm{hijkl}} \pm 0.01$ & $5.33^{\mathrm{jk}} \pm 0.02$ & $5.89^{\mathrm{klmn}} \pm 0.09$ \\
\hline WF40/1E & $9.00^{\mathrm{d}} \pm 0.25$ & $2.28^{\text {ghijkl }} \pm 0.00$ & $5.43^{\mathrm{ij}} \pm 0.02$ & $6.24^{\mathrm{ijk}} \pm 0.07$ \\
\hline WF50/1E & $9.00^{\mathrm{d}} \pm 0.25$ & $2.30^{\mathrm{efgh}} \pm 0.02$ & $5.62^{\mathrm{gh}} \pm 0.01$ & $7.03^{\mathrm{gh}} \pm 0.04$ \\
\hline WF60/1E & $8.50^{\mathrm{e}} \pm 0.29$ & $2.33^{\text {bcdef }} \pm 0.01$ & $5.67^{\text {gh }} \pm 0.01$ & $7.33^{\mathrm{fg}} \pm 0.01$ \\
\hline WF70/1E & $8.50^{\mathrm{e}} \pm 0.29$ & $2.37^{\mathrm{abcd}} \pm 0.01$ & $5.75^{\mathrm{efg}} \pm 0.01$ & $7.88^{\text {bcd }} \pm 0.01$ \\
\hline WF80/1E & $8.50^{\mathrm{e}} \pm 0.14$ & $2.35^{\text {abcde }} \pm 0.01$ & $5.86^{\mathrm{def}} \pm 0.01$ & $8.02^{\mathrm{abcd}} \pm 0.07$ \\
\hline WF90/1E & $8.50^{\mathrm{e}} \pm 0.25$ & $2.35^{\text {abcde }} \pm 0.01$ & $5.90^{\text {cde }} \pm 0.02$ & $8.09^{\mathrm{abcd}} \pm 0.04$ \\
\hline WF100/1E & $8.00^{\mathrm{g}} \pm 0.14$ & $2.35^{\text {abcde }} \pm 0.01$ & $5.99^{\mathrm{bcd}} \pm 0.05$ & $8.34^{\mathrm{abc}} \pm 0.06$ \\
\hline $\mathrm{WF} 0 / 2 \mathrm{E}$ & $9.75^{\mathrm{a}} \pm 0.14$ & $2.29^{\text {efghi }} \pm 0.03$ & $4.98^{\circ} \pm 0.03$ & $5.09^{p} \pm 0.11$ \\
\hline $\mathrm{WF} 10 / 2 \mathrm{E}$ & $9.50^{\mathrm{b}} \pm 0.14$ & $2.31^{\text {cdefg }} \pm 0.02$ & $5.07^{\mathrm{mno}} \pm 0.03$ & $5.18^{\mathrm{op}} \pm 0.06$ \\
\hline WF20/2E & $9.50^{\mathrm{b}} \pm 0.29$ & $2.30^{\mathrm{efgh}} \pm 0.01$ & $5.15^{\operatorname{lmn}} \pm 0.03$ & $5.28^{\text {nop }} \pm 0.01$ \\
\hline WF30/2E & $9.25^{\mathrm{c}} \pm 0.14$ & $2.31^{\operatorname{cdefg}} \pm 0.01$ & $5.24^{\mathrm{klm}} \pm 0.02$ & $5.43^{\mathrm{mnop}} \pm 0.07$ \\
\hline $\mathrm{WF} 40 / 2 \mathrm{E}$ & $9.25^{\mathrm{c}} \pm 0.14$ & $2.33^{\text {cdef }} \pm 0.01$ & $5.37^{\mathrm{jk}} \pm 0.04$ & $5.56^{\mathrm{lmn}} \pm 0.23$ \\
\hline WF50/2E & $9.25^{\mathrm{c}} \pm 0.14$ & $2.33^{\mathrm{cdef}} \pm 0.01$ & $5.45^{\mathrm{ij}} \pm 0.03$ & $5.70^{\mathrm{klmn}} \pm 0.01$ \\
\hline WF60/2E & $9.25^{\mathrm{c}} \pm 0.14$ & $2.33^{\text {bcdef }} \pm 0.01$ & $5.55^{\mathrm{hi}} \pm 0.03$ & $5.71^{\mathrm{klmn}} \pm 0.15$ \\
\hline WF70/2E & $9.00^{\mathrm{d}} \pm 0.29$ & $2.34^{\text {abcdef }} \pm 0.01$ & $5.65^{\mathrm{gh}} \pm 0.03$ & $6.06^{\mathrm{jkl}} \pm 0.05$ \\
\hline WF80/2E & $9.00^{d} \pm 0.14$ & $2.38^{\mathrm{abc}} \pm 0.01$ & $5.79^{\mathrm{efg}} \pm 0.04$ & $7.00^{\mathrm{gh}} \pm 0.03$ \\
\hline WF90/2E & $9.00^{\mathrm{d}} \pm 0.14$ & $2.40^{\mathrm{ab}} \pm 0.01$ & $5.87^{\text {cde }} \pm 0.04$ & $7.31^{\mathrm{efg}} \pm 0.11$ \\
\hline WF100/2E & $9.00^{\mathrm{d}} \pm 0.00$ & $2.41^{\mathrm{a}} \pm 0.01$ & $5.88^{\text {cde }} \pm 0.04$ & $7.96^{\text {bcd }} \pm 0.01$ \\
\hline
\end{tabular}

$\mathrm{WF}$ - common wheat flour, E- egg.

Means $(n=4)$ with different letters in the same column are significantly different $(P<0.05)$. 
Teterycz, D., Sobota, A., Kozłowicz, K., Zarzycki, P. (2019). Substitution of semolina durum with common wheat flour in egg and eggless pasta. Acta Sci. Pol. Technol. Aliment., 18(4), 439-451. http://dx.doi.org/10.17306/J.AFS.2019.0722

depends on the composition of the egg component. The addition of egg white caused an increase in the WII, while the addition of egg yolks caused a decrease in the weight increase index. Yolk represents only $1 / 3$ of the egg weight; therefore, adding whole eggs also increased the amount of water absorbed by the pasta.

The cooking losses of the pasta should not exceed $8 \%$ (Dick and Youngs, 1988). The value of this parameter is largely influenced by the degree of damage to the starch granules (Liu et al., 2014). All the samples prepared met the criterion. It is also worth noting that all the two-egg, one-egg samples with $0-70 \%$ common wheat flour content and eggless samples with $0-60 \%$ common wheat flour content met this criterion even during overcooking.

\section{Colour parameters of pasta}

The colour of pasta is determined by the pigment content in the raw materials, in this case durum semolina, common wheat flour and eggs. Durum wheat grains are richer in carotenoids than common wheat grains and, therefore, durum-based products have a darker and more yellow colour (Leenhardt et al., 2006). The $L^{*}$ parameter indicating the brightness of the pasta decreased significantly as the proportion of semolina in the sample increased, both for raw and cooked pasta, but the cooked pasta became lighter (Table 5). The addition of eggs to the pasta reduced the $L^{*}$ parameter of raw pasta, but these differences were statistically significant only for a few two-egg samples with the highest content of common wheat flour (WF100/2E,

Table 5. Colour parameters of cooked and uncooked pasta samples

\begin{tabular}{|c|c|c|c|c|c|c|c|c|}
\hline \multirow{2}{*}{ Sample } & \multicolumn{4}{|c|}{ Uncooked pasta } & \multicolumn{4}{|c|}{ Cooked pasta } \\
\hline & $L^{*}$ & $a^{*}$ & $b^{*}$ & $\mathrm{YI}_{(\mathrm{FC})}$ & $L^{*}$ & $a^{*}$ & $b^{*}$ & $\mathrm{YI}_{(\mathrm{FC})}$ \\
\hline 1 & 2 & 3 & 4 & 5 & 6 & 7 & 8 & 9 \\
\hline WF0/0E & $\begin{array}{l}52.66^{\text {mnopqr }} \\
\pm 0.30\end{array}$ & $\begin{array}{r}0.97^{\mathrm{j}} \\
\pm 0.02\end{array}$ & $\begin{array}{l}14.84^{\text {def }} \\
\pm 0.47\end{array}$ & $\begin{array}{l}40.27^{\text {def }} \\
\pm 1.05\end{array}$ & $\begin{array}{l}63.07^{\mathrm{jklm}} \\
\pm 0.25\end{array}$ & $\begin{array}{l}-0.69^{\mathrm{ab}} \\
\pm 0.07\end{array}$ & $\begin{array}{l}10.91^{\text {cdef }} \\
\pm 0.14\end{array}$ & $\begin{array}{l}24.71^{\text {efg }} \\
\pm 0.27\end{array}$ \\
\hline WF10/0E & $\begin{array}{l}52.87^{\mathrm{mnopq}} \\
\pm 0.888\end{array}$ & $\begin{array}{r}0.95^{\mathrm{j}} \\
\pm 0.04\end{array}$ & $\begin{array}{l}14.64^{\mathrm{efg}} \\
\pm 0.29\end{array}$ & $\begin{array}{l}39.57^{\mathrm{def}} \\
\pm 1.00\end{array}$ & $\begin{array}{l}63.59^{\text {hijkl }} \\
\pm 0.99\end{array}$ & $\begin{array}{l}-0.89^{\text {defghi }} \\
\pm 0.05\end{array}$ & $\begin{array}{l}10.54^{\text {ef }} \\
\pm 0.30\end{array}$ & $\begin{array}{l}23.69^{\text {ghij }} \\
\pm 0.70\end{array}$ \\
\hline WF20/0E & $\begin{array}{l}53.14^{\mathrm{mnop}} \\
\pm 1.11\end{array}$ & $\begin{array}{r}0.94^{j} \\
\pm 0.03\end{array}$ & $\begin{array}{l}14.32^{\text {efgh }} \\
\pm 0.34\end{array}$ & $\begin{array}{l}38.51^{\text {efg }} \\
\pm 0.36\end{array}$ & $\begin{array}{l}63.64^{\mathrm{hijkl}} \\
\pm 0.85\end{array}$ & $\begin{array}{l}-0.93^{\text {fghi }} \\
\pm 0.04\end{array}$ & $\begin{array}{l}10.43^{\text {efg }} \\
\pm 0.74\end{array}$ & $\begin{array}{l}23.43^{\text {hij }} \\
\pm 1.70\end{array}$ \\
\hline WF30/0E & $\begin{array}{l}53.26^{\mathrm{Imno}} \\
\pm 1.94\end{array}$ & $\begin{array}{r}0.93^{\mathrm{j}} \\
\pm 0.13\end{array}$ & $\begin{array}{l}14.29^{\mathrm{fgh}} \\
\pm 1.61\end{array}$ & $\begin{array}{l}38.26^{\text {efgh }} \\
\pm 3.12\end{array}$ & $\begin{array}{l}64.24^{\text {fghij }} \\
\pm 1.20\end{array}$ & $\begin{array}{l}-0.92^{\text {efghi }} \\
\pm 0.02\end{array}$ & $\begin{array}{l}10.26^{\mathrm{fg}} \\
\pm 0.08\end{array}$ & $\begin{array}{l}22.83^{\mathrm{ijk}} \\
\pm 0.36\end{array}$ \\
\hline WF40/0E & $\begin{array}{l}56.25^{\text {hijk }} \\
\pm 0.33\end{array}$ & $\begin{array}{c} \\
0.77^{\mathrm{k}} \\
\pm 0.11\end{array}$ & $\begin{array}{l}14.04^{\text {fghi }} \\
\pm 0.55\end{array}$ & $\begin{array}{l}35.66^{\mathrm{hij}} \\
\pm 1.20\end{array}$ & $\begin{array}{l}65.75^{\text {efghij }} \\
\pm 2.43\end{array}$ & $\begin{array}{l}-0.98^{\text {ghi }} \\
\pm 0.17\end{array}$ & 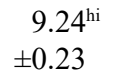 & $\begin{array}{l}20.10^{\operatorname{lm}} \\
\pm 1.03\end{array}$ \\
\hline WF50/0E & $\begin{array}{l}56.45^{\text {ghijk }} \\
\pm 2.84\end{array}$ & $\begin{array}{c}0.74^{\mathrm{k}} \\
\pm 0.12\end{array}$ & $\begin{array}{l}13.40^{\mathrm{hijk}} \\
\pm 0.97\end{array}$ & $\begin{array}{l}33.89^{\mathrm{j} \mathrm{jk}} \\
\pm 0.92\end{array}$ & $\begin{array}{l}65.65^{\text {efghij }} \\
\pm 1.00\end{array}$ & $\begin{array}{l}-1.17^{\mathrm{jk}} \\
\pm 0.10\end{array}$ & $\begin{array}{l}9.21^{\mathrm{hi}} \\
\pm 0.61\end{array}$ & $\begin{array}{l}20.06^{\mathrm{m}} \\
\pm 1.49\end{array}$ \\
\hline WF60/0E & $\begin{array}{l}57.63^{\text {efghi }} \\
\pm 0.93\end{array}$ & $\begin{array}{r}0.73^{\mathrm{k}} \\
\pm 0.06\end{array}$ & $\begin{array}{l}12.62^{\mathrm{jkl}} \\
\pm 0.58\end{array}$ & $\begin{array}{l}31.26^{\mathrm{klmn}} \\
\pm 0.96\end{array}$ & $\begin{array}{l}65.57^{\text {efghij }} \\
\pm 1.57\end{array}$ & $\begin{array}{l}-1.17^{\mathrm{jk}} \\
\pm 0.10\end{array}$ & $\begin{aligned} & 8.26^{\mathrm{jkl}} \\
\pm & 0.32\end{aligned}$ & $\begin{array}{l}18.00^{\text {nop }} \\
\pm 0.31\end{array}$ \\
\hline WF70/0E & $\begin{array}{l}59.25^{\text {cdef }} \\
\pm 0.86\end{array}$ & $\begin{array}{l} \\
0.71^{\mathrm{kl}} \\
\pm 0.02\end{array}$ & $\begin{array}{l}12.24^{\mathrm{kl}} \\
\pm 0.31\end{array}$ & $\begin{array}{l}29.51^{\mathrm{mno}} \\
\pm 0.36\end{array}$ & $\begin{array}{l}66.66^{\mathrm{ef}} \\
\pm 1.75\end{array}$ & $\begin{array}{l}-1.21^{\mathrm{k}} \\
\pm 0.05\end{array}$ & $\begin{array}{l}8.00^{\mathrm{klm}} \\
\pm 0.06\end{array}$ & $\begin{array}{l}17.16^{\mathrm{pqr}} \\
\pm 0.52\end{array}$ \\
\hline WF80/0E & $\begin{array}{l}60.21^{\text {bcd }} \\
\pm 0.59\end{array}$ & $\begin{array}{c}0.69^{\mathrm{kl}} \\
\pm 0.05\end{array}$ & $\begin{array}{l}12.14^{\mathrm{kl}} \\
\pm 0.39\end{array}$ & $\begin{array}{l}28.79^{\text {mnop }} \\
\pm 0.64\end{array}$ & $\begin{array}{l}69.87^{\mathrm{bc}} \\
\pm 1.09\end{array}$ & $\begin{array}{l}-1.22^{\mathrm{k}} \\
\pm 0.09\end{array}$ & $\begin{array}{l}7.54^{\mathrm{lm}} \\
\pm 0.53\end{array}$ & $\begin{array}{l}15.40^{\mathrm{rs}} \\
\pm 0.94\end{array}$ \\
\hline WF90/0E & $\begin{array}{l}61.86^{\mathrm{ab}} \\
\pm 3.40\end{array}$ & $\begin{array}{r}0.56^{1} \\
\pm 0.02\end{array}$ & $\begin{array}{l}11.70^{1} \\
\pm 0.37\end{array}$ & $\begin{array}{l}27.12^{\mathrm{op}} \\
\pm 2.12\end{array}$ & $\begin{array}{l}71.65^{\mathrm{abc}} \\
\pm 0.96\end{array}$ & $\begin{array}{l}-1.24^{\mathrm{k}} \\
\pm 0.12\end{array}$ & $\begin{array}{l}7.20^{\mathrm{mn}} \\
\pm 0.07\end{array}$ & $\begin{array}{l}14.35^{\text {st }} \\
\pm 0.10\end{array}$ \\
\hline WF100/0E & $\begin{array}{l}62.80^{\mathrm{a}} \\
\pm 0.66\end{array}$ & $\begin{array}{r}0.55^{1} \\
\pm 0.07\end{array}$ & $\begin{array}{l}11.64^{1} \\
\pm 0.70\end{array}$ & $\begin{array}{l}26.47^{p} \\
\pm 1.32\end{array}$ & $\begin{array}{l}72.54^{\mathrm{a}} \\
\pm 1.59\end{array}$ & $\begin{array}{l}-1,54^{1} \\
\pm 0.12\end{array}$ & $\begin{array}{r}6.13^{\circ} \\
\pm 0.53\end{array}$ & $\begin{array}{l}12.06^{u} \\
\pm 0.85\end{array}$ \\
\hline
\end{tabular}


Teterycz, D., Sobota, A., Kozłowicz, K., Zarzycki, P. (2019). Substitution of semolina durum with common wheat flour in egg and eggless pasta. Acta Sci. Pol. Technol. Aliment., 18(4), 439-451. http://dx.doi.org/10.17306/J.AFS.2019.0722

Table 5 - cont.

\begin{tabular}{|c|c|c|c|c|c|c|c|c|}
\hline 1 & 2 & 3 & 4 & 5 & 6 & 7 & 8 & 9 \\
\hline WF0/1E & $\begin{array}{l}51.39^{\text {opqr }} \\
\pm 1.62\end{array}$ & $\begin{aligned} & 1.84^{\mathrm{f}} \\
\pm & 0.11\end{aligned}$ & $\begin{array}{l}16.81^{\mathrm{b}} \\
\pm 0.59\end{array}$ & $\begin{array}{l}46.75^{\mathrm{b}} \\
\pm 0.46\end{array}$ & $\begin{array}{l}61.56^{\mathrm{lnno}} \\
\pm 1.25\end{array}$ & $\begin{array}{l}-0.70^{\text {abc }} \\
\pm 0.09\end{array}$ & $\begin{array}{l}11.15^{\text {bcdef }} \\
\pm 0.87\end{array}$ & $\begin{array}{l}25.85^{\text {def }} \\
\pm 1.52\end{array}$ \\
\hline WF10/1E & $\begin{array}{l}52.79^{\text {Imnopqr }} \\
\pm 0.87\end{array}$ & $\begin{aligned} & 1.67^{\mathrm{g}} \\
\pm & 0.02\end{aligned}$ & $\begin{array}{l}16.70^{\mathrm{b}} \\
\pm 0.32\end{array}$ & $\begin{array}{l}45.21^{\mathrm{b}} \\
\pm 1.00\end{array}$ & $\begin{array}{l}62.95^{\mathrm{klmn}} \\
\pm 1.45\end{array}$ & $\begin{array}{l}-0.72^{\mathrm{abc}} \\
\pm 0.01\end{array}$ & $\begin{array}{l}10.77^{\text {def }} \\
\pm 0.69\end{array}$ & $\begin{array}{l}24.42^{\text {fghi }} \\
\pm 1.04\end{array}$ \\
\hline WF20/1E & $\begin{array}{l}53.09^{\text {Imnop }} \\
\pm 0.89\end{array}$ & $\begin{array}{l}1.67^{\mathrm{g}} \\
\pm 0.02\end{array}$ & $\begin{array}{l}16.63^{\mathrm{bc}} \\
\pm 0.60\end{array}$ & $\begin{array}{l}44.73^{\mathrm{bc}} \\
\pm 1.02\end{array}$ & $\begin{array}{l}63.81^{\text {hijkl }} \\
\pm 0.67\end{array}$ & $\begin{array}{l}-0.76^{\text {abcdef }} \\
\pm 0.06\end{array}$ & $\begin{array}{l}10.33^{\mathrm{fg}} \\
\pm 0.67\end{array}$ & $\begin{array}{l}23.11^{\text {hijk }} \\
\pm 1.37\end{array}$ \\
\hline WF30/1E & $\begin{array}{l}54.85^{\mathrm{jklm}} \\
\pm 0.61\end{array}$ & $\begin{aligned} & 1.64^{\mathrm{g}} \\
\pm & 0.04\end{aligned}$ & $\begin{array}{l}16.05^{\mathrm{bcd}} \\
\pm 0.32\end{array}$ & $\begin{array}{l}41.80^{\text {cd }} \\
\pm 0.54\end{array}$ & $\begin{array}{l}63.86^{\text {ghijkl }} \\
\pm 1.12\end{array}$ & $\begin{array}{l}-0.83^{\text {bcdefg }} \\
\pm 0.08\end{array}$ & $\begin{array}{l}10.47^{\text {efg }} \\
\pm 0.49\end{array}$ & $\begin{array}{l}23.39^{\mathrm{hij}} \\
\pm 0.71\end{array}$ \\
\hline WF40/1E & $\begin{array}{l}57.23^{\text {fghij }} \\
\pm 0.62\end{array}$ & $\begin{array}{l}1.51^{\mathrm{gh}} \\
\pm 0.06\end{array}$ & $\begin{array}{l}15.13^{\text {def }} \\
\pm 0.53\end{array}$ & $\begin{array}{l}37.78^{\text {fgh }} \\
\pm 1.06\end{array}$ & $\begin{array}{l}63.92^{\text {ghijkl }} \\
\pm 1.43\end{array}$ & $\begin{array}{l}-0.89^{\text {defghi }} \\
\pm 0.11\end{array}$ & $\begin{array}{l}9.54^{\mathrm{gh}} \\
\pm 0.24\end{array}$ & $\begin{array}{l}21.37^{\mathrm{kl}} \\
\pm 0.20\end{array}$ \\
\hline WF50/1E & $\begin{array}{l}58.85^{\text {fghij }} \\
\pm 0.37\end{array}$ & $\begin{aligned} & 1.42^{\mathrm{hi}} \\
\pm & 0.05\end{aligned}$ & $\begin{array}{l}13.46^{\text {ghij }} \\
\pm 1.20\end{array}$ & $\begin{array}{l}33.84^{\mathrm{ijk}} \\
\pm 2.85\end{array}$ & $\begin{array}{l}65.39^{\text {efghijk }} \\
\pm 1.13\end{array}$ & $\begin{array}{l}-0.92^{\text {defghi }} \\
\pm 0.09\end{array}$ & 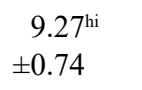 & $\begin{array}{l}20.21^{\mathrm{mn}} \\
\pm 1.32\end{array}$ \\
\hline WF60/1E & $\begin{array}{l}58.09^{\text {defgh }} \\
\pm 0.42\end{array}$ & $\begin{aligned} & 1.41^{\mathrm{hi}} \\
\pm & 0.06\end{aligned}$ & $\begin{array}{l}13.29^{\text {hijk }} \\
\pm 0.82\end{array}$ & $\begin{array}{l}32.67^{\mathrm{kl}} \\
\pm 1.81\end{array}$ & $\begin{array}{l}65.51^{\text {efghijk }} \\
\pm 0.87\end{array}$ & $\begin{array}{l}-0.93^{\text {fghi }} \\
\pm 0.09\end{array}$ & $\begin{array}{l}\quad 8.88^{\text {hijk }} \\
\pm 0.80\end{array}$ & $\begin{array}{l}20.01^{\mathrm{mn}} \\
\pm 1.87\end{array}$ \\
\hline WF70/1E & $\begin{array}{l}58.44^{\text {defgh }} \\
\pm 0.57\end{array}$ & $\begin{aligned} & 1.37^{\mathrm{hi}} \\
\pm & 0.07\end{aligned}$ & $\begin{array}{l}12.78^{\mathrm{jkl}} \\
\pm 0.54\end{array}$ & $\begin{array}{l}31.24^{\mathrm{klmn}} \\
\pm 1.20\end{array}$ & $\begin{array}{l}66.45^{\mathrm{efg}} \\
\pm 1.33\end{array}$ & $\begin{array}{l}-0.93^{\text {fghi }} \\
\pm 0.09\end{array}$ & $\begin{aligned} & 8.01^{\mathrm{klm}} \\
\pm & 0.51\end{aligned}$ & $\begin{array}{l}18.45^{\text {op }} \\
\pm 0.78\end{array}$ \\
\hline WF80/1E & $\begin{array}{l}59.86^{\text {bcde }} \\
\pm 0.89\end{array}$ & $\begin{array}{r}1.30^{\mathrm{i}} \\
\pm 0.06\end{array}$ & $\begin{array}{l}12.59^{\mathrm{jkl}} \\
\pm 0.42\end{array}$ & $\begin{array}{l}30.06^{\text {Imno }} \\
\pm 1.13\end{array}$ & $\begin{array}{l}\quad 67.23^{\mathrm{de}} \\
\pm 01.05\end{array}$ & $\begin{array}{l}-0.97^{\text {ghi }} \\
\pm 0.03\end{array}$ & $\begin{array}{l}7.57^{\mathrm{lm}} \\
\pm 0.14\end{array}$ & $\begin{array}{l}17.10^{\text {gr }} \\
\pm 0.09\end{array}$ \\
\hline WF90/1E & $\begin{array}{l}60.40^{\mathrm{abcd}} \\
\pm 0.26\end{array}$ & $\begin{array}{r}1.26^{\mathrm{i}} \\
\pm 0.01\end{array}$ & $\begin{array}{l}12.13^{\mathrm{kl}} \\
\pm 0.23\end{array}$ & $\begin{array}{l}28.70^{\text {nop }} \\
\pm 0.43\end{array}$ & $\begin{array}{l}71.35^{\mathrm{abc}} \\
\pm 1.48\end{array}$ & $\begin{array}{l}-1.02^{\mathrm{hij}} \\
\pm 0.06\end{array}$ & $\begin{aligned} & 7.32^{\mathrm{m}} \\
\pm & 0.46\end{aligned}$ & $\begin{array}{l}15.64^{\mathrm{rs}} \\
\pm 0.63\end{array}$ \\
\hline WF100/1E & $\begin{array}{l}61.76^{\mathrm{abc}} \\
\pm 1.74\end{array}$ & $\begin{array}{r}1.25^{\mathrm{i}} \\
\pm 0.05\end{array}$ & $\begin{array}{l}12.11^{\mathrm{kl}} \\
\pm 0.20\end{array}$ & $\begin{array}{l}28.02^{\mathrm{op}} \\
\pm 0.47\end{array}$ & $\begin{array}{l}72.33^{\mathrm{ab}} \\
\pm 1.03\end{array}$ & $\begin{array}{l}-1.03^{\mathrm{ij}} \\
\pm 0.03\end{array}$ & $\begin{array}{l}\quad 6.37^{\text {no }} \\
\pm 0.32\end{array}$ & $\begin{array}{l}13.58^{\mathrm{t}} \\
\pm 0.45\end{array}$ \\
\hline WF0/2E & $\begin{array}{l}50.26^{\mathrm{r}} \\
\pm 1.54\end{array}$ & $\begin{array}{r}2.63^{\mathrm{a}} \\
\pm 0.10\end{array}$ & $\begin{array}{l}19.30^{\mathrm{a}} \\
\pm 0.53\end{array}$ & $\begin{array}{l}54.90^{\mathrm{a}} \\
\pm 0.66\end{array}$ & $\begin{array}{l}58.28^{p} \\
\pm 0.83\end{array}$ & $\begin{array}{l}-0.66^{\mathrm{a}} \\
\pm 0.03\end{array}$ & $\begin{array}{l}14.23^{\mathrm{a}} \\
\pm 0.39\end{array}$ & $\begin{array}{l}34.90^{\mathrm{a}} \\
\pm 1.15\end{array}$ \\
\hline WF10/2E & $\begin{array}{l}50.43^{\mathrm{qr}} \\
\pm 0.30\end{array}$ & $\begin{aligned} & 2.28^{\mathrm{b}} \\
\pm & 0.13\end{aligned}$ & $\begin{array}{l}18.84^{\mathrm{a}} \\
\pm 1.14\end{array}$ & $\begin{array}{l}53.38^{\mathrm{a}} \\
\pm 3.27\end{array}$ & $\begin{array}{l}59.70^{\mathrm{op}} \\
\pm 1.08\end{array}$ & $\begin{array}{l}-0.69^{\mathrm{ab}} \\
\pm 0.02\end{array}$ & $\begin{array}{l}13.77^{\mathrm{a}} \\
\pm 0.55\end{array}$ & $\begin{array}{l}32.97^{\mathrm{b}} \\
\pm 1.01\end{array}$ \\
\hline WF20/2E & $\begin{array}{l}50.69^{\mathrm{pqr}} \\
\pm 1.64\end{array}$ & $\begin{aligned} & 2.23^{\mathrm{bc}} \\
\pm & 0.05\end{aligned}$ & $\begin{array}{l}18.58^{\mathrm{a}} \\
\pm 0.27\end{array}$ & $\begin{array}{l}52.39^{\mathrm{a}} \\
\pm 1.04\end{array}$ & $\begin{array}{l}60.40^{\text {nop }} \\
\pm 1.08\end{array}$ & $\begin{array}{l}-0.74^{\mathrm{abcd}} \\
\pm 0.10\end{array}$ & $\begin{array}{l}13.62^{\mathrm{a}} \\
\pm 0.21\end{array}$ & $\begin{array}{l}32.22^{\mathrm{b}} \\
\pm 0.24\end{array}$ \\
\hline WF30/2E & $\begin{array}{l}52.23^{\text {nopqr }} \\
\pm 1.90\end{array}$ & $\begin{aligned} & 2.19^{\mathrm{bc}} \\
\pm & 0.17\end{aligned}$ & $\begin{array}{l}16.87^{\mathrm{b}} \\
\pm 0.95\end{array}$ & $\begin{array}{l}46.24^{\mathrm{b}} \\
\pm 3.72\end{array}$ & $\begin{array}{l}60.99^{\mathrm{mno}} \\
\pm 2.50\end{array}$ & $\begin{array}{l}-0.76^{\text {abcde }} \\
\pm 0.13\end{array}$ & $\begin{array}{l}10.07^{\mathrm{b}} \\
\pm 0.61\end{array}$ & $\begin{array}{l}28.27^{\mathrm{c}} \\
\pm 0.86\end{array}$ \\
\hline WF40/2E & $\begin{array}{l}54.12^{1 \mathrm{kmn}} \\
\pm 0.96\end{array}$ & $\begin{array}{l}2.11^{\mathrm{cd}} \\
\pm 0.03\end{array}$ & $\begin{array}{l}15.45^{\text {cde }} \\
\pm 0.22\end{array}$ & $\begin{array}{l}40.79^{\text {de }} \\
\pm 0.30\end{array}$ & $\begin{array}{l}63.27^{\mathrm{ijklm}} \\
\pm 0.13\end{array}$ & $\begin{array}{l}-0.85^{\text {cdefgh }} \\
\pm 0.02\end{array}$ & $\begin{array}{l}11.98^{\mathrm{b}} \\
\pm 0.37\end{array}$ & $\begin{array}{l}27.06^{\mathrm{cd}} \\
\pm 0.81\end{array}$ \\
\hline WF50/2E & $\begin{array}{l}55.33^{\mathrm{ijkl}} \\
\pm 0.47\end{array}$ & $\begin{aligned} & 2.07^{\text {cde }} \\
\pm & 0.04\end{aligned}$ & $\begin{array}{l}14.87^{\text {def }} \\
\pm 0.79\end{array}$ & $\begin{array}{l}38.38^{\text {efgh }} \\
\pm 1.76\end{array}$ & $\begin{array}{l}63.94^{\mathrm{ghijkl}} \\
\pm 1.33\end{array}$ & $\begin{array}{l}-0.89^{\text {defghi }} \\
\pm 0.03\end{array}$ & $\begin{array}{l}11.94^{\mathrm{bc}} \\
\pm 0.57\end{array}$ & $\begin{array}{l}26.66^{\text {cde }} \\
\pm 0.94\end{array}$ \\
\hline WF60/2E & $\begin{array}{l}56.50^{\mathrm{ghijk}} \\
\pm 0.41\end{array}$ & $\begin{array}{l}2.06^{\text {cde }} \\
\pm 0.19\end{array}$ & $\begin{array}{l}14.83^{\text {def }} \\
\pm 0.39\end{array}$ & $\begin{array}{l}37.50^{\mathrm{fgh}} \\
\pm 0.74\end{array}$ & $\begin{array}{l}65.82^{\text {efghi }} \\
\pm 1.43\end{array}$ & $\begin{array}{l}-0.91^{\text {efghi }} \\
\pm 0.04\end{array}$ & $\begin{array}{l}11.63^{\mathrm{bcd}} \\
\pm 0.29\end{array}$ & $\begin{array}{l}25.27^{\mathrm{efg}} \\
\pm 0.81\end{array}$ \\
\hline WF70/2E & $\begin{array}{l}57.43^{\text {efghij }} \\
\pm 1.30\end{array}$ & $\begin{array}{l}1.99^{\text {def }} \\
\pm 0.22\end{array}$ & $\begin{array}{l}14.55^{\text {efg }} \\
\pm 0.37\end{array}$ & $\begin{array}{l}36.26^{\text {ghi }} \\
\pm 1.28\end{array}$ & $\begin{array}{l}66.16^{\mathrm{efgh}} \\
\pm 0.70\end{array}$ & $\begin{array}{l}-0.92^{\text {efghi }} \\
\pm 0.02\end{array}$ & $\begin{array}{l}11.27^{\text {bcde }} \\
\pm 0.37\end{array}$ & $\begin{array}{l}24.35^{\text {fghi }} \\
\pm 1.03\end{array}$ \\
\hline WF80/2E & $\begin{array}{l}57.58^{\text {efghi }} \\
\pm 0.98\end{array}$ & $\begin{array}{c}1.91^{\mathrm{ef}} \\
\pm 0.06\end{array}$ & $\begin{array}{l}14.44^{\text {efgh }} \\
\pm 0.34\end{array}$ & $\begin{array}{l}35.83^{\text {ghij }} \\
\pm 0.35\end{array}$ & $\begin{array}{l}67.12^{\mathrm{de}} \\
\pm 1.24\end{array}$ & $\begin{array}{l}-0.91^{\text {efghi }} \\
\pm 0.01\end{array}$ & $\begin{array}{l}10.71^{\text {def }} \\
\pm 0.18\end{array}$ & $\begin{array}{l}22.80^{\mathrm{ijk}} \\
\pm 0.13\end{array}$ \\
\hline WF90/2E & $\begin{array}{l}58.75^{\text {defgh }} \\
\pm 0.58\end{array}$ & $\begin{aligned} & 1.85^{\mathrm{f}} \\
\pm & 0.04\end{aligned}$ & $\begin{array}{l}13.57^{\text {ghij }} \\
\pm 0.32\end{array}$ & $\begin{array}{l}33.01^{\mathrm{jk} 1} \\
\pm 0.68\end{array}$ & $\begin{array}{l}69.47^{\mathrm{cd}} \\
\pm 0.39\end{array}$ & $\begin{array}{l}-0.95^{\text {ghi }} \\
\pm 0.05\end{array}$ & $\begin{array}{l}10.84^{\text {def }} \\
\pm 0.08\end{array}$ & $\begin{array}{l}22.30^{\mathrm{jk}} \\
\pm 0.10\end{array}$ \\
\hline WF100/2E & $\begin{array}{l}58.81^{\text {defg }} \\
\pm 0.43\end{array}$ & $\begin{aligned} & 1.51^{\mathrm{gh}} \\
\pm & 0.03\end{aligned}$ & $\begin{array}{l}13.03^{\mathrm{ijk}} \\
\pm 0.24\end{array}$ & $\begin{array}{l}31.67^{\mathrm{klm}} \\
\pm 0.39\end{array}$ & $\begin{array}{l}70.19^{\mathrm{abc}} \\
\pm 1.10\end{array}$ & $\begin{array}{l}-0.97^{\text {ghi }} \\
\pm 0.05\end{array}$ & $\begin{aligned} & 8.70^{\mathrm{ijk}} \\
\pm & 0.26\end{aligned}$ & $\begin{array}{l}21.30^{\mathrm{kl}} \\
\pm 0.28\end{array}$ \\
\hline
\end{tabular}

WF - common wheat flour, E - egg. Mean $(n=10)$ with different letters in the same column are significantly different $(P<0.05)$. 
Teterycz, D., Sobota, A., Kozłowicz, K., Zarzycki, P. (2019). Substitution of semolina durum with common wheat flour in egg and eggless pasta. Acta Sci. Pol. Technol. Aliment., 18(4), 439-451. http://dx.doi.org/10.17306/J.AFS.2019.0722

Table 6. The value of correlation coefficient (Pearson) between chemical composition and cooking quality of pasta

\begin{tabular}{|c|c|c|c|c|c|}
\hline \multirow[b]{2}{*}{ Egg addition } & \multirow{2}{*}{$\begin{array}{l}\text { Chemical } \\
\text { composition }\end{array}$} & \multicolumn{4}{|c|}{ Cooking quality } \\
\hline & & $\begin{array}{l}\text { minimal cooking } \\
\text { time }\end{array}$ & $\begin{array}{l}\text { weight increase } \\
\text { index }\end{array}$ & cooking loss & overcooking loss \\
\hline \multirow[t]{5}{*}{0} & protein & $0.92 *$ & $-0.97 *$ & $-0.96^{*}$ & $-0.98^{*}$ \\
\hline & fat & $0.94 *$ & $-0.88^{*}$ & $-0.91 *$ & $-0.86^{*}$ \\
\hline & TDF & $0.93^{*}$ & $-0.99 *$ & $-0.98^{*}$ & $-0.99^{*}$ \\
\hline & ash & $0.92 *$ & $-0.97 *$ & $-0.97 *$ & $-0.97 *$ \\
\hline & carbohydrates & $-0.93 *$ & $0.98 *$ & $0.97 *$ & $0.99 *$ \\
\hline \multirow[t]{5}{*}{1} & protein & $0.90^{*}$ & $-0.92 *$ & $-0.99 *$ & $-0.95^{*}$ \\
\hline & fat & 0.46 & $-0.63 *$ & $-0.61^{*}$ & -0.53 \\
\hline & TDF & $0.88^{*}$ & $-0.95 *$ & $-0.99 *$ & $-0.95^{*}$ \\
\hline & ash & $0.81 *$ & $-0.97 *$ & $-0.98 *$ & $-0.95^{*}$ \\
\hline & carbohydrates & $-0.88^{*}$ & $0.95^{*}$ & $0.99 *$ & $0.96^{*}$ \\
\hline \multirow[t]{5}{*}{2} & protein & $0.82 *$ & $-0.93 *$ & $-0.99 *$ & $-0.92 *$ \\
\hline & fat & $0.77 *$ & $-0.83^{*}$ & $-0.89^{*}$ & $-0.81^{*}$ \\
\hline & TDF & $0.85^{*}$ & $-0.96^{*}$ & $-0.99 *$ & $-0.94 *$ \\
\hline & ash & $0.88 *$ & $-0.92 *$ & $-0.99 *$ & $-0.88^{*}$ \\
\hline & carbohydrates & $-0.84^{*}$ & $0.94 *$ & $0.99 *$ & $0.93^{*}$ \\
\hline
\end{tabular}

*Correlation coefficient statistically significant $(P<0.05)$.

WF90/2E, and WF80/2E). On the other hand, the $a^{*}$ parameter significantly increased for samples with the higher content of semolina and with the addition of eggs. The $b^{*}$ parameter also increases, but it was statistically significant only for samples with the addition of two eggs. The increase in parameters $a^{*}$ and $b^{*}$ with the addition of eggs was determined by the high content of carotenoids in egg yolk; adding this each time increased the yellowness and redness of the pasta. A similar relation was observed in the case of the cooked pasta. The $L^{*}$ parameter decreased significantly only for a few two-egg samples. The $a^{*}$ parameter increased for the one- and two-egg samples, whereas the increase in the $b^{*}$ parameter was statistically significant only for the two-egg pasta. The yellow index (YI) is an important parameter of pasta. The study assumed that it should be higher than 30 and 20 for raw and cooked pasta, respectively. The results showed that YI increased with both the semolina and egg content in the pasta and ranged from 26.47 to 54.90 in the raw pasta. The yellowness index criterion for the raw samples was met by eggless samples with the addition of common wheat flour at a maximum level of $60 \%$, one-egg samples with common wheat flour at a level up to $80 \%$, and all two-egg samples. In the case of the cooked pasta, eggless samples with a common wheat flour content ranging from $60 \%$ to $100 \%$ and one-egg samples with a common wheat flour content ranging from $70 \%$ to $100 \%$ did not meet the criterion for the yellowness index of 20 .

\section{CONCLUSION}

Based on the analysis of the results and criteria for the production of pasta with the specified quality parameters, it can be concluded that it is possible to produce 
Teterycz, D., Sobota, A., Kozłowicz, K., Zarzycki, P. (2019). Substitution of semolina durum with common wheat flour in egg and eggless pasta. Acta Sci. Pol. Technol. Aliment., 18(4), 439-451. http://dx.doi.org/10.17306/J.AFS.2019.0722

high-quality pasta from a mixture of durum semolina and common wheat flour. Replacing up to $50 \%$ of the semolina with common flour in eggless pasta yields a product that meets all the criteria adopted in the study. The addition of eggs significantly improves the quality parameters of pasta, increasing its fibre and protein content, and improving its colour and cooking features. For one-egg pasta, the addition of $60 \%$ common wheat flour is accepted. However, adding two eggs to the pasta seems to be the most suitable. All pasta samples with the addition of two eggs, regardless of the semolina and common flour ratio, met all the quality criteria (protein content $\min .11 .5 \%$; dietary fibre min. 3.8\%; cooking loss max. $8 \%$; yellowness index (YI) min. 30 and 20 or raw and cooked pasta, respectively). The results of these studies indicate that semolina durum can be fully replaced by common wheat flour, which can significantly reduce production costs in countries where access to durum wheat is limited. It is worth noting that the addition of two eggs per $1 \mathrm{~kg}$ of common wheat flour is cheaper than using durum semolina for pasta production. Greater addition of eggs to common wheat pasta would enhance the quality. However, the product would be more expensive than semolina pasta.

\section{REFERENCES}

Abdou, A. M., Kim, M., Sato, K. (2013). Functional proteins and peptides of hen's egg origin. In B. Hernández-Ledesma (Ed.), Bioactive food peptides in health and disease (pp. 115-143). Rijeka, Croatia: InTech.

Alamprese, C. (2017). The use of egg and egg products in pasta production. In P.Y. Hester (Ed.), Egg innovations and strategies for improvements (1st ed., pp. 251-260). London, England: Academic Press.

Alamprese, C., Iametti, S., Rossi, M., Bergonzi, D. (2005). Role of pasteurisation heat treatments on rheological and protein structural characteristics of fresh egg pasta. Eur. Food Res. Technol., 221(6), 759-767.

AOAC (1992). AOAC official methods of analysis. Washington, D.C., USA: AOAC International.

AACC (2000). Approved methods of the American Association of Cereal Chemist. St. Paul, USA: American Association of Cereal Chemist.

Bonet, A., Blaszczak W., Rosell, C. M. (2006). Formation of homopolymers and heteropolymers between wheat flour and several protein sources by transglutaminasecatalyzed cross-linking. Cereal Chem., 83, 6, 655-662.

Dalbon, G., Grivon, D., Pagani, M. A. (1996). Continuous manufacturing process. In J. E. Kruger, R. B. Matsuo, J. W. Dick (Eds.), Pasta and noodle technology (pp. 1358). St. Paul: American Association of Cereal Chemists. Diantom, A., Carini, E., Curti, E., Cassotta, F., D’Alessandro, A., Vittadini, E. (2016). Effect of water and gluten on physico-chemical properties and stability of ready to eat shelf-stable pasta. Food Chem., 195, 91-96.

Dick, J. W., Youngs, V. L. (1988). Evaluation of durum wheat, semolina, and pasta in the United States. In G. Fabriani, C. Lintas (Eds.), Durum wheat. Chemistry and technology (pp. 238-248). St. Paul, USA: AACC Press.

Filipovic, J., Miladinovic, Z., Pezo, L., Filipovic, N., Filipovic, V., Jevtic-Vukmirovic, A. (2014). Quality of spelt pasta enriched with eggs and identification of eggs using 13C MAS NMR spectroscopy. Hem. Ind., 69(1), 59-65.

Francis, F. J., Clydesdale, F. M. (1975). Food colorimetry: Theory and applications. Westport, Ireland: AVI Publ.

Fuad, T., Prabhasankar, P. (2010). Role of ingredients in pasta product quality: A review on recent developments. Crit. Rev. Food Sci. Nutr., 50, 8, 787-798. https://doi. org/10.1080/10408390903001693

Grant, L. A., Dick, J. W., Shelton, D. R. (1993). Effects of drying temperature, starch damage, sprouting and additives on spaghetti quality characteristics. Cereal Chem., 70, 676-676.

Jyotsna, R., Prabhasankar, P., Indrani, D., Venkateswara Rao, G. (2004). Effect of additives on the quality and microstructure of vermicelli made from Triticum aestivum. Eur. Food Res. Technol., 218(6), 557-562.

Lafiandra, D., Masci, S., Sissons, M., Dornez, E., Delcour, J. A., Courtin, C. M., Caboni, M. F. (2012). Kernel components of technological value. In M. Sissons (Ed.), Durum wheat chemistry and technology ( $2^{\text {nd }}$ ed., pp. 85-124). St. Paul: AACC International. https://doi.org/10.1016/ B978-1-891127-65-6.50011-8

Lambrecht, M. A., Rombouts, I., Nivelle, M. A., Delcour, J. A. (2017). The role of wheat and egg constituents in the formation of a covalent and non-covalent protein network in fresh and cooked egg noodles. J. Food Sci., 82, 1, 24-35. https://doi.org/10.1111/1750-3841.13558

Leenhardt, F., Lyan, B., Rock, E., Boussard, A., Potus, J., Chanliaud, E., Remesy, C. (2006). Genetic variability of carotenoid concentration, and lipoxygenase and peroxidase activities among cultivated wheat species and bread wheat varieties. Eur. J. Agron., 25, 2, 170-176. https://doi.org/10.1016/j.eja.2006.04.010 
Teterycz, D., Sobota, A., Kozłowicz, K., Zarzycki, P. (2019). Substitution of semolina durum with common wheat flour in egg and eggless pasta. Acta Sci. Pol. Technol. Aliment., 18(4), 439-451. http://dx.doi.org/10.17306/J.AFS.2019.0722

Liu, C., Li, L., Hong, J., Zheng, X., Bian, K., Sun, Y., Zhang, J. (2014). Effect of mechanically damaged starch on wheat flour, noodle and steamed bread making quality. Int. J. Food Sci. Technol., 49, 1, 253-260.

Mann, J. I., Cummings, J. H. (2009). Possible implications for health of the different definitions of dietary fibre. Nutr. Metab. Cardiovasc. Dis., 19, 3, 226-229. https:// doi.org/10.1016/j.numecd.2009.02.002

Manthey, F., Twombly, W. (2013). Extruding and drying of pasta. In Y. H. Hui, J. D. Culbertson (Eds.), Handbook of food science, technology and engineering (pp. 158.1158.15). CRC Press.

Marti, A., Pagani, M. A., Seetharaman, K. (2014). Textural attributes of wheat and gluten free pasta. In Y. L. Dar, J. M. Light (Eds.), Food texture design and optimization (pp. 222-244). New Jersey: Wiley-Blackwell. https:// doi.org/10.1002/9781118765616.ch9

Mehta, N., Ahlawat, S. S., Sharma, D. P., Dabur, R. S. (2015). Novel trends in development of dietary fiber rich meat products - a critical review. J. Food Sci. Technol., 52(2), 633-647.

Miranda, J. M., Anton, X., Redondo-Valbuena, C., RocaSaavedra, P., Rodriguez, J. A., Lamas, A., Franco, C. M. Cepeda, A. (2015). Egg and egg-derived foods: Effects on human health and use as functional foods. Nutrients, 7, 1, 706-729. https://doi.org/10.3390/nu7010706

Panyoo, A. E., Emmambux, M. N. (2017). Amylose-lipid complex production and potential health benefits: A mini-review. Starch-Stärke, 69, 7-8, 1600203. https://doi. org/10.1002/star.201600203

PN-A-74131:1999. Makaron [Pasta]. Warszawa: PKN [in Polish].

Rafiq, A., Sharma, S., Singh, B. (2017). In vitro starch digestibility, degree of gelatinization and functional properties of twin screw prepared cereal-legume pasta. J. Cereal Sci., 74, 279-287. https://doi.org/10.1016/j. jcs.2017.03.001

Rakonjac, S., Bogosavljević-Bošković, S., Pavlovski, Z., Škrbić, Z., Dosković, V., Petrovic, M. D., Petričević, V. (2014). Laying hen rearing systems: A review of chemical composition and hygienic conditions of eggs. World Poult. Sci. J., 70, 1, 151-164. https://doi.org/10.1017/ S0043933914000130

Regolamento per la revisione della normativa sulla produzione e commercializzazione di sfarinati e paste alimentari, a norma dell'articolo 50 della legge 22 febbraio 1994 (1994). n. 146. § 4.3.57 - D.P.R. 9 febbraio 2001, n. 187.
Ruxton, C. H. S., Derbyshire, E., Gibson, S. (2010). The nutritional properties and health benefits of eggs. Nutr. Food Sci., 40, 3, 263-279. https://doi.org/10.1108/0034 6651011043961

Savita, S., Arshwinder, K., Gurkirat, K., Vikas, N. (2013). Influence of different protein sources on cooking and sensory quality of pasta. Int. J. Eng. Res. Appl., 3, 2, 1757-1763.

Sobota, A., Rzedzicki, Z., Zarzycki, P., Kuzawińska, E. (2015a). Application of common wheat bran for the industrial production of high-fibre pasta. Int. J. Food Sci. Technol., 50, 111-119.

Sobota, A., Rzedzicki, Z., Zarzycki, P., Wirkijowska, A., Sykut-Domańska, E. (2015b). Changes in content of free fat during egg pasta manufacturing process. Żywn. Nauka Technol. Jakość, 5, 102, 152-164. https://doi. org/10.15193/zntj/2015/102/079

Sobota, A., Zarzycki, P. (2013). Effect of pasta cooking time on the content and fractional composition of dietary fiber. J. Food Qual., 36, 2, 127-132. http://doi.org/10.1111/ jfq. 12023

Sobota, A., Zarzycki, P., Kuzawinska, E., Wirkijowska, A., Sykut-Domanska, E. (2017). Jakość wybranych surowców makaronowych dostępnych na rynku polskim [Quality of selected raw pasta materials available on the Polish market]. Przegl. Zboż.-Młyn., 61, 6, 20-25 [in Polish].

Sozer, N., Kaya, A. (2008). The effect of cooking water composition on textural and cooking properties of spaghetti. Int. J. Food Prop., 11, 351-362.

Švec, I., Hrušková, M., Vítová, M., Sekerová, H. (2008). Colour evaluation of different pasta samples. Czech J. Food Sci., 26(6), 421-427.

Teterycz, D., Sobota, A., Zarzycki, P. Latoch, A. (2019). Legume flour as a natural colouring component in pasta production. J. Food Sci. Technol. https://doi. org/10.1007/s13197-019-04061-5

USDA (2015). Scientific report of the 2015 Dietary Guidelines Advisory Committee. Washington, D.C.: Department of Health and Human Services. United States Department of Agriculture.

Watkins, B. A. (1995). The nutritive value of eggs. In W. J. Stadelman, O. J. Cotterill (Eds.), Egg science and technology (4th ed., pp. 177-190). New York - London: Food Products Press.

Wiseman, G. (2001). Durum wheat. In R. C. Kill, K. Turnbull (Eds.), Pasta and semolina technology (pp. 11-42). Oxford, United Kingdom: Blackwell Science. 